\title{
Neuroectodermal Neoplasms of the Head and Neck with Emphasis on Neuroendocrine Carcinomas
}

\author{
Stacey E. Mills, M.D. \\ Robert E. Fechner Laboratory of Surgical Pathology, University of Virginia Health Sciences Center, \\ Charlottesville, Virginia
}

Tumors exhibiting neuroectodermal differentiation occur throughout the body, and the diverse tissues of the head and neck give rise to a wide assortment of these neoplasms. Neuroectodermal neoplasms may be divided into lesions showing primarily epithelial differentiation (Group I, neuroendocrine carcinomas) and a more diverse group (Group II) of nonepithelial neoplasms. This article reviews these neuroectodermal tumors of the head and neck with emphasis on the neuroendocrine carcinomas and their nomenclature. The author believes that with regard to Group I tumors, the older terminology of carcinoid, atypical carcinoid, and small cell carcinoma should be replaced by subclassifications of well-differentiated, moderately differentiated, and poorly differentiated neuroendocrine carcinoma. The latter category should be further subdivided into small cell and large cell variants. Neuroendocrine carcinomas, particularly the moderately differentiated subtype, are often underdiagnosed in the head and neck region. In the larynx, these tumors are the most common form of nonsquamous carcinoma. Poorly differentiated neuroendocrine carcinoma of small cell type is most common in the salivary glands but can occur elsewhere in the region. The large cell subtype of poorly differentiated neuroendocrine carcinoma has not been well documented in this region. However, the most likely candidate for this tumor category is the so-called sinonasal undifferentiated carcinoma. Group II tumors discussed include olfactory neuroblastoma, malignant melanoma, and Ewing's sarcoma. In addition, differential diagnostic problems related to Group I and II tumors are reviewed in detail. This article reviews and updates our understanding of neuroectodermal neoplasms arising in the head and

Copyright (C) 2002 by The United States and Canadian Academy of Pathology, Inc.

VOL. 15, NO. 3, P. 264, 2002 Printed in the U.S.A.

Date of acceptance: September 28, 2001

Address reprint requests to: Stacey E. Mills, M.D., Department of Pathology, P.O. Box 800214, University of Virginia Health Sciences Center, Jefferson Park Avenue, Charlottesville, VA 22908; e-mail: sem2r@ virginia.edu; fax: 434-924-8767. neck. The focus is on tumors that exclusively involve this region or show a strong predilection to occur here.

KEY WORDS: Head and neck, Malignant melanoma, Neuroectodermal neoplasms, Neuroendocrine carcinoma, Nomenclature, Olfactory neuroblastoma, PNET, Sinonasal undifferentiated carcinoma.

Mod Pathol 2002;15(3):264-278

Neuroectodermal neoplasms at any anatomic site can be divided into tumors showing epithelial differentiation (Group I) and tumors with predominantly neural features (Group II). In the head and neck (Table 1), Group I lesions such as neuroendocrine carcinoma of the larynx typically exhibit cytokeratin positivity and are often admixed with other forms of carcinoma. Group II tumors, such as olfactory neuroblastoma are typically (but not invariably) cytokeratin negative and are more often phenotypically "pure" neoplasms. Although, as will be discussed, not all tumors fit neatly into this classification scheme, the great majority do, making it a useful overall construct.

Early authors describing Group I neuroendocrine neoplasms throughout the body, especially the well-differentiated forms (carcinoid) considered these unique lesions requiring a well-defined neuroendocrine precursor cell for their development. When such cells were not readily apparent in normal tissue counterparts by a variety of techniques, the authors often felt compelled to go to great lengths to explain the tumor's origin. We now recognize that epithelial cells (or at least their progenitors) in virtually every organ have the ability to exhibit neuroendocrine differentiation. Moreover, light-microscopically obvious neuroendocrine differentiation is not uncommonly admixed with squamous or glandular elements, particularly when dealing with higher grade lesions. Fortunately, these older, nonproductive discussions regarding "cell of origin" have given way to more clinically relevant studies seeking to understand the clinicopathologic features of these tumors. 
TABLE 1. Neuroectodermal Neoplasms of the Head and Neck: Nomenclature

Group 1

Well-differentiated neuroendocrine carcinoma (carcinoid tumor)

Moderately differentiated neuroendocrine carcinoma (atypical carcinoid tumor

Poorly differentiated neuroendocrine carcinoma, small cell type Poorly differentiated neuroendocrine carcinoma, large cell type Pituitary adenoma/carcinoma

Group 2

Granular cell tumor

Heterotopic glial tissue

Malignant peripheral nerve sheath tumor

Malignant melanoma

Neurofibroma

Olfactory neuroblastoma

Paraganglioma

PNET/Ewing's sarcoma

Schwannoma

PNET, peripheral neuroectodermal tumor.

\section{NOMENCLATURE}

The terminology surrounding Group I neuroendocrine neoplasia at any anatomic site remains in a state of considerable flux. In 1993, the World Health Organization (WHO) divided laryngeal neuroendocrine neoplasms into carcinoid, atypical carcinoid, and small cell carcinoma (1). I believe that there are several problems with this approach, particularly with regard to the term atypical carcinoid tumor. Most important, this term requires clinician understanding that in fact, an atypical carcinoid is an overtly malignant, often high-grade neoplasm, meriting an aggressive clinical approach. This is counterintuitive to a name that seems more closely allied to the indolent typical carcinoid tumor.

Although much is written about the morphologic spectrum of neuroendocrine tumors, it is not entirely clear whether typical carcinoid tumor is a member of a blurred spectrum of neoplasms or an entity distinct from higher grades of neuroendocrine neoplasia. Typical carcinoid tumor of the larynx (or lung) appears to be unrelated to smoking, whereas all other forms of neuroendocrine neoplasia in the larynx (or lung) show a striking association. Most so-called atypical carcinoid tumors are obvious, often highly malignant-appearing neoplasms. In contrast, typical carcinoid tumors are almost never associated with areas of significant cytologic atypia. Finally, so-called atypical carcinoids and small cell carcinomas will often show divergent differentiation with foci of squamous or glandular cells. Such features are extremely rare in typical carcinoid tumors. In other words, typical carcinoid tumor may be a morphologically and clinically distinct lesion having little or no overlap with other, higher grade neuroendocrine proliferations. Therefore, it may be argued that such tumors should be distinguished by being the sole neoplasms to carry the "carcinoid" designation. The argument against this approach emphasizes the need for uniform terminology and the fact that carcinoid tumors, even the typical type, can metastasize.

Some authors have suggested for the lung that the term atypical carcinoid should be retained for a narrowed set of lesions showing most of the features of typical carcinoid but with increased mitotic activity, greater nuclear pleomorphism, and focal necrosis $(2,3)$. Some lesions considered to be atypical carcinoids in earlier studies have been relegated to the more recently described diagnostic category of large cell neuroendocrine carcinoma (4). In the head and neck, lesions in both categories are rare, and their biologic behavior is correspondingly poorly understood. It has not been convincingly proven, for example, that atypical carcinoids, stage for stage in the head and neck, are any different in their biologic behavior from higher grade neuroendocrine carcinomas.

I believe that the term atypical carcinoid should be abandoned, even when used to designate a restricted group of lesions with some features of carcinoid tumor. There is simply too much confusion among clinicians with regard to the meaning of this term. The terminology that I favor for neuroendocrine neoplasia is outlined in Table 1. Under this system, typical carcinoid tumors are designated as well-differentiated neuroendocrine carcinomas, followed in print, at least for now, by (carcinoid tumor) to make certain that the clinician understands the meaning of this designation. So-called atypical carcinoid tumors are designated as moderately differentiated neuroendocrine carcinomas, a term that more accurately reflects their biologic potential. This system also recognizes poorly differentiated neuroendocrine carcinomas of both small cell and large cell subtypes.

The World Health Organization (WHO) classification of ear, nose, and throat (ENT) tumors included no category for large-cell neuroendocrine carcinomas, a relatively recently recognized entity in the lung and some other sites. In the former location, such tumors appear to fall into two categories: large cell, light-microscopically undifferentiated carcinomas with occult neuroendocrine differentiation detectable only at the immunohistochemical or ultrastructural level and high-grade carcinomas composed of larger cells, with some neuroendocrine features at the light-microscopic level. The former tumors have not been characterized in the ENT region. The latter appear to merge with the high-grade end of the moderately differentiated category described below. 


\section{NEUROENDOCRINE CARCINOMAS AND RELATED NEOPLASMS (GROUP 1)}

The majority of neuroendocrine neoplasms in the head and neck region arise from the larynx. The (distant) second most common site is the salivary glands. In the former location, the tumors are predominantly of moderate differentiation. In the latter location, they are typically of the poorly differentiated, small cell subtype.

The first "neuroendocrine carcinoma" of the larynx was reported in 1969 by Goldman et al., who referred to the lesion as a "carcinoid tumor" (5). Subsequently, a considerable number of such cases have been reported as carcinoids, atypical carcinoids, malignant carcinoids, and neuroendocrine carcinomas (5-23). In some of these earlier discussions, the cytologic and clinical features of the tumors were overtly malignant, yet the term carcinoid tumor was applied without further modification, emphasizing the nomenclature problem discussed above.

\section{Well-Differentiated Neuroendocrine Carcinoma (Typical Carcinoid Tumor)}

A review by El-Naggar and Batsakis (24) addressed the issue of so-called true or typical carcinoid tumors of the larynx. These authors indicated that no more than a dozen such cases have been adequately described (24). The welldifferentiated neuroendocrine carcinoma, or "typical carcinoid tumor," predominantly involves the supraglottic larynx, often in the region of the arytenoid or aryepiglottic fold. Only one of the 13 patients in the review by El-Naggar and Batsakis died of disease. Three other patients had metastases to liver, bone, lymph node, and skin. Despite this, these individuals were still alive 4 to 8 years after diagnosis (24). This biologic behavior (33\% metastases) is significantly different from that of bronchial well-differentiated neuroendocrine carcinoma (carcinoid tumor) and suggests that with more adequate study, one or more of these tumors may have been reclassified as more aggressive neoplasms (moderately differentiated neuroendocrine carcinoma). Overall, however, the behavior of this group of tumors is significantly better than that of higher grade neuroendocrine neoplasms. Microscopically, these tumors are identical to well-differentiated neuroendocrine carcinomas (carcinoid tumors) occurring at more common anatomic sites. The tumors grow in nests and cords composed of relatively uniform cells with characteristic "salt \& pepper" chromatin (Fig. 1). In my practice, I have encountered only two of these in the larynx. Both were confused with a laryngeal paraganglioma.

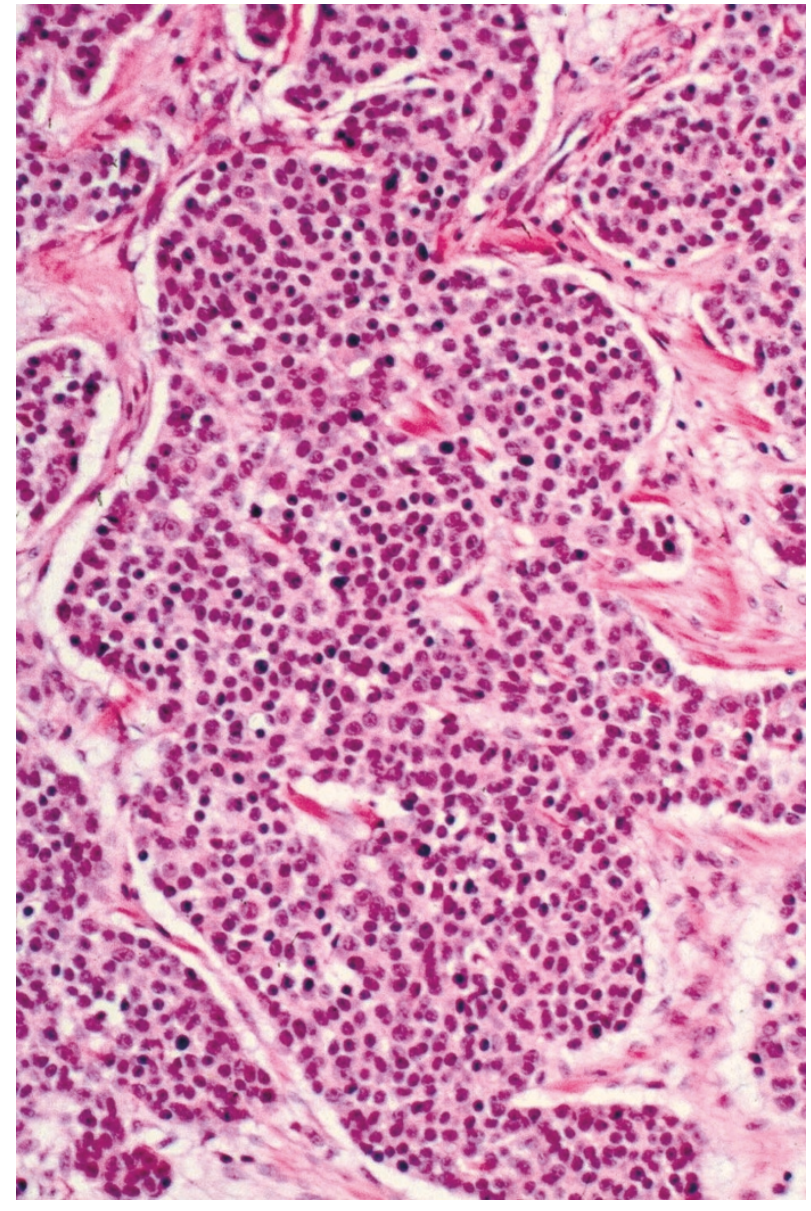

FIGURE 1. A well-differentiated neuroendocrine carcinoma ("carcinoid" tumor) of the larynx consists of sharply demarcated nests of uniform cells.

Helpful differential diagnostic features are discussed below.

\section{"Carcinoid" of the Middle Ear}

There have been several publications dealing with so-called carcinoid tumors of the middle ear (25-29). It seems clear that these lesions are better interpreted as middle ear adenomas (MEA). MEA can certainly have a carcinoid-like appearance (Fig. 2), but this is only one of their multiple growth patterns. Some MEA may even exhibit partial neuroendocrine differentiation, based on immunohistochemical marker studies. However, MEA (even with neuroendocrine differentiation) appear to behave in a completely benign fashion. Labeling them as "carcinoids" or, worse, well-differentiated neuroendocrine carcinomas, is confusing, particularly to clinicians, and is only marginally supported morphologically.

\section{Moderately Differentiated Neuroendocrine Carcinoma}

As noted above, most neuroendocrine neoplasms of the larynx seem to be tumors of mod- 


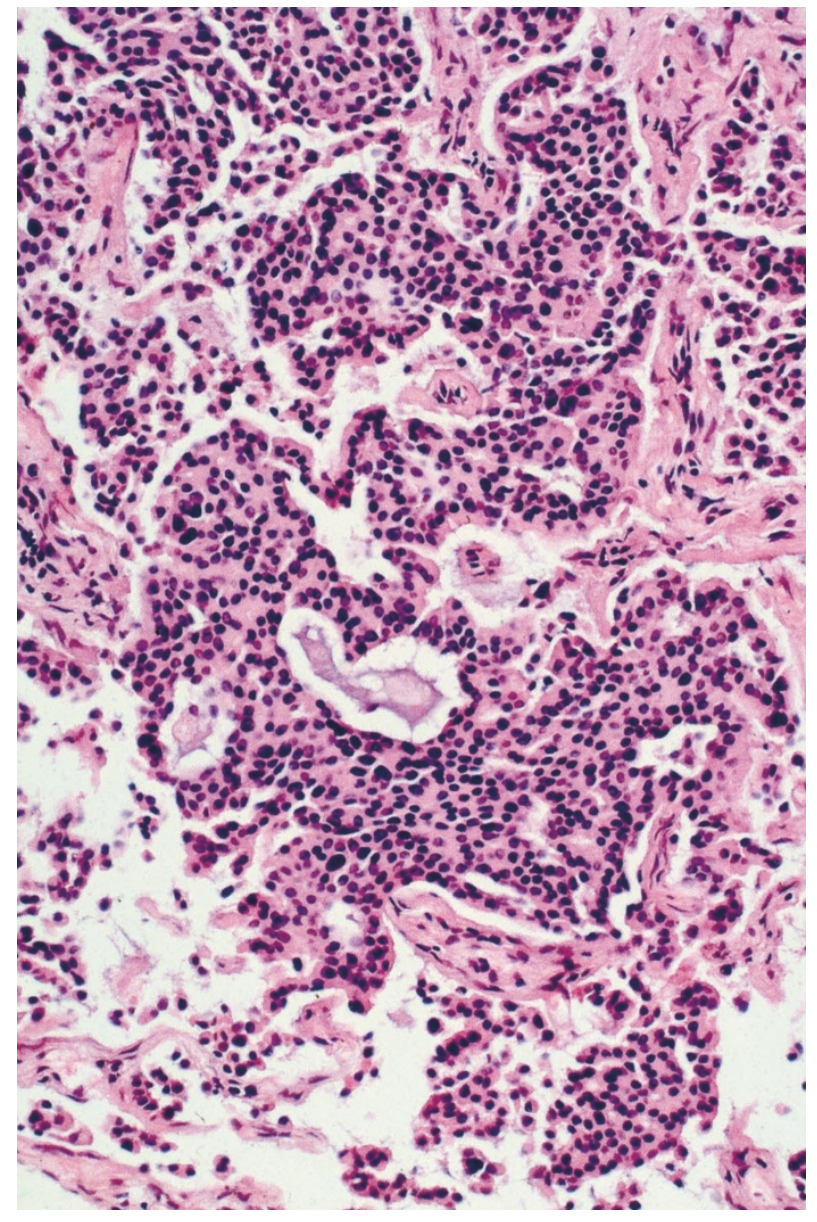

FIGURE 2. Middle-ear adenomas may consists of sharply demarcated cell nests indistinguishable from those of "carcinoid tumor."

erate differentiation, referred to by varying terms. These are not rare neoplasms, and many have previously gone unrecognized. In fact, several studies have indicated that these are the most common nonsquamous malignancies of the larynx $(30,31)$.

There have been several relatively large series of moderately differentiated laryngeal neuroendocrine carcinomas (32-34). There is a strong male predilection, and a high percentage of patients have been cigarette smokers. The light microscopic features are identical to those of analogous pulmonary neoplasms. The tumors show some carcinoidlike features with a tendency to grow in nests and cords of cells, often with peripheral palisading of nuclei (Fig. 3). However, there are obvious mitotic figures coupled with mild to moderate nuclear pleomorphism, well beyond that typically seen in a welldifferentiated neuroendocrine carcinoma. Immunohistochemically, the neoplastic cells are typically positive for synaptophysin, cytokeratin, chromogranin, calcitonin, and carcinoembryonic antigen (CEA) (34).

Surgical resection is the primary mode of therapy. Of 127 cases with follow-up in Woodruff and

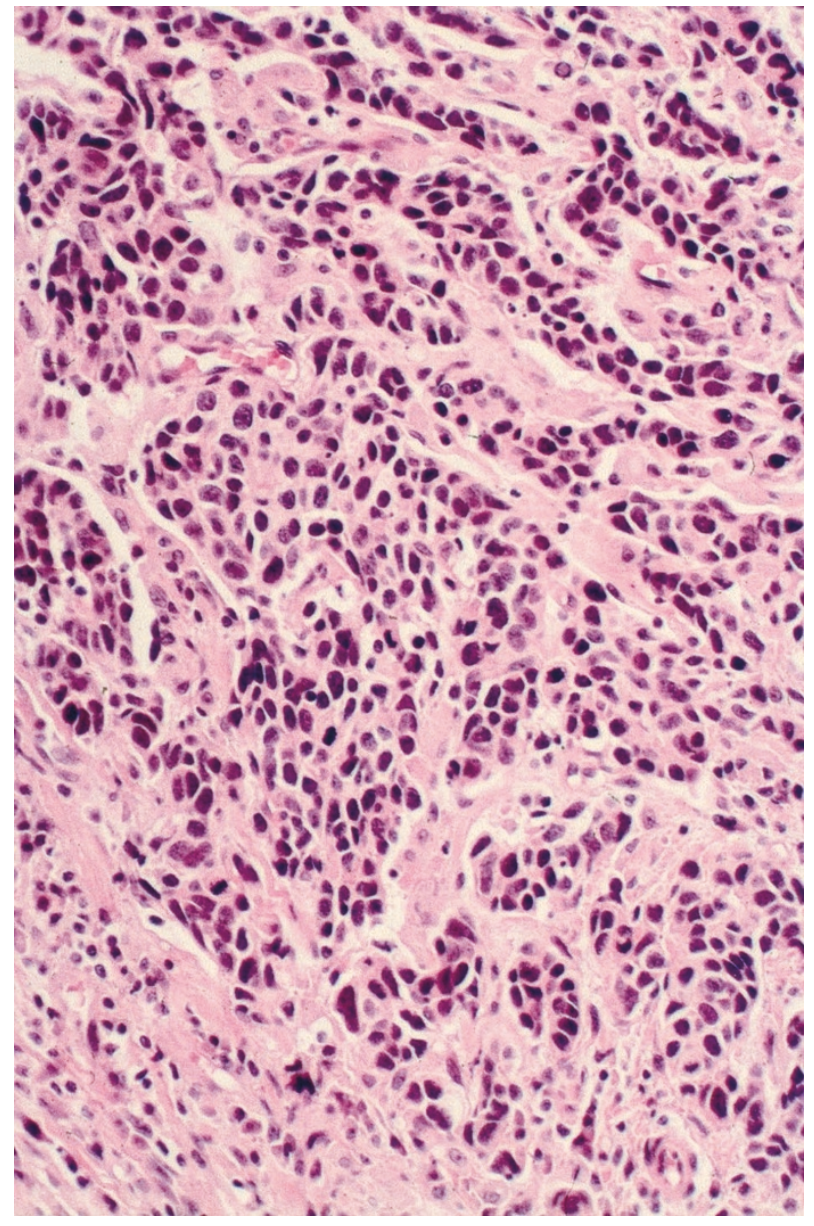

FIGURE 3. Moderately differentiated neuroendocrine carcinoma of the larynx contains more irregular cell nests composed of moderately pleomorphic cells with increased mitotic activity. Small foci of necrosis may also be present.

Senie's review (34), 43\% had regional lymph node metastases, $22 \%$ had metastases to skin or subcutaneous tissues, and $44 \%$ had distant spread. The overall 5 -year survival was $48 \%$, and 10 -year survival was $30 \%$. Radiation therapy did not significantly improve survival. This important fact emphasizes the need to distinguish these tumors from more radiation-sensitive squamous cell carcinomas (34). The responsiveness of these lesions to different chemotherapy regimens is not well documented.

\section{Poorly Differentiated Neuroendocrine Carcinoma, Small Cell Type}

These tumors are often referred to as small cell undifferentiated carcinoma or small cell neuroendocrine carcinoma (SCNC), depending on the degree to which at least abortive neuroendocrine differentiation has been documented. Once potentially confusing lesions such as basaloid squamous cell carcinoma and the solid variant of adenoid cystic carcinoma have been excluded, the amount (if any) 
of documented neuroendocrine differentiation seems to have no relationship to prognosis. As of now, there are no well or moderately differentiated small cell neuroendocrine carcinomas, so SCNC is an acceptable synonym for the longer term listed above. SCNC of the larynx are uncommon but wellrecognized neoplasms $(32,35-49)$. In a review by Gnepp (49), almost three fourths of patients died of widespread metastases. Two- and five-year survival rates were similar to those for pulmonary SCNC. There was a strong male predominance, and most patients were heavy smokers. Microscopically, the tumors were indistinguishable from their pulmonary counterparts (Fig. 4). Foci of squamous or glandular differentiation were occasionally noted $(48,49)$.

Because of the poorly differentiated nature of the tumor, immunohistochemical stains are of limited value. Occasional cases have shown positivity for chromogranin, neuron-specific enolase, calcitonin, adrenocorticotropic hormone, $\beta$-endorphin, gastrinsecreting polypeptide, and carcinoembryonic antigen $(13,30,49-51)$.

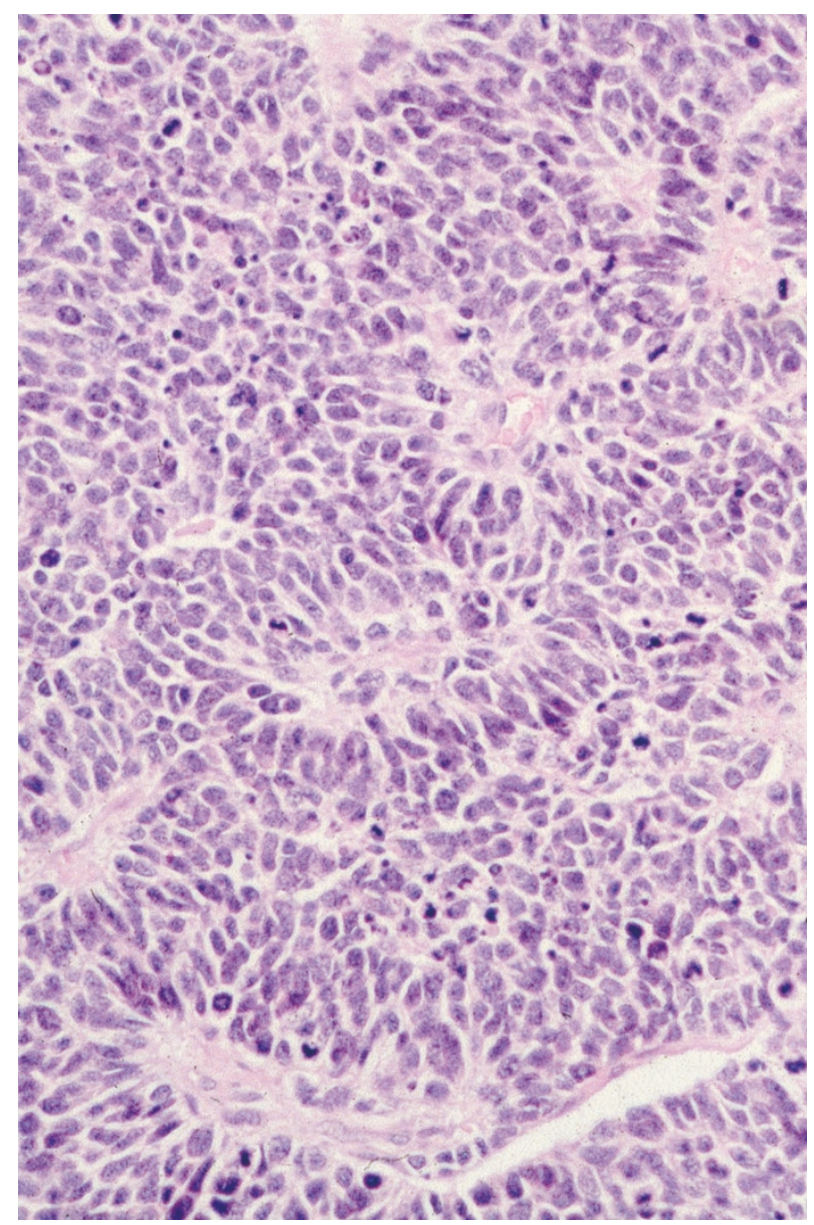

FIGURE 4. Poorly differentiated neuroendocrine carcinoma of the larynx, small cell type, consists of cords of pleomorphic cells with a very high nuclear to cytoplasmic ratio.
As mentioned above, SCNC needs to be distinguished from basaloid squamous cell carcinoma of the larynx, a more common neoplasm with which it may easily be confused (see differential diagnosis, below).

\section{Salivary SCNC}

SCNC have been described arising from both major and minor salivary glands. Salivary SCNC account for about $2 \%$ of parotid gland carcinomas and about $3.5 \%$ of minor salivary gland malignancies. There is a broad age range that includes patients under 30 years of age, but most are over 50 years old at the time of diagnosis. A male predilection is strongly suggested, but the total number of cases is small.

These tumors are indistinguishable at the lightmicroscopic level from "oat-cell" carcinomas of the lung. Sheets of spindled to ovoid cells with little or no visible cytoplasm; a very high mitotic rate; and abundant, often infarctlike geographic necrosis are typical. In our experience, multiple sections of SCNC arising in the parotid gland have invariably

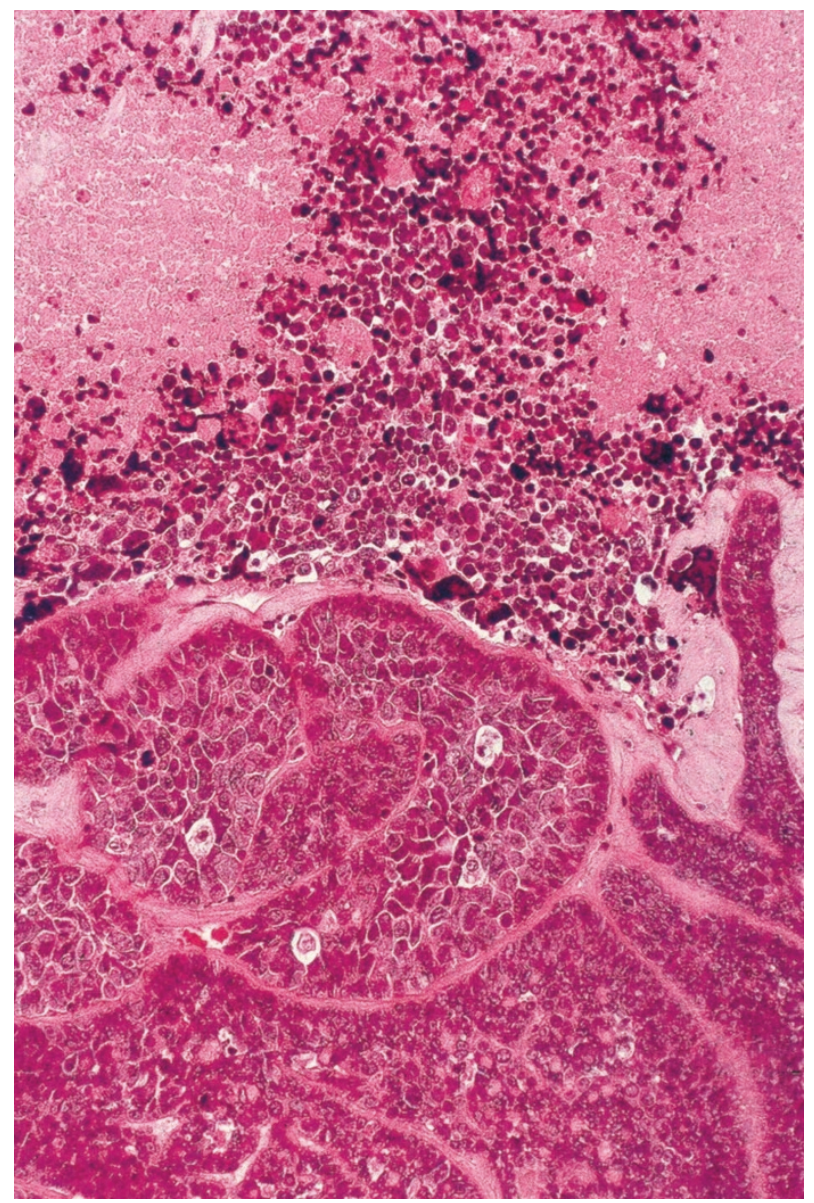

FIGURE 5. This poorly differentiated neuroendocrine carcinoma, small cell type (top), of the parotid gland also includes a better differentiated glandular component (bottom), which resembles a basal cell adenocarcinoma 
demonstrated areas of better differentiated carcinoma (adenocarcinoma; Fig. 5). Immunohistochemical stains have demonstrated divergent differentiation in such cases. The presence of a better differentiated component may be a helpful feature in distinguishing these lesions from metastatic SCNC.

SCNC of the salivary glands appears to have a better prognosis than that of analogous tumors occurring at most other locations. The 2-year and 5 -year survival rates for SCNC of the major salivary glands have been reported as $70 \%$ and $46 \%$, respectively (52). This is considerably better than the survival rates for SCNC at other head and neck sites, such as the larynx (see above). Metastases from salivary SCNC tend to disseminate hematogenously, and cervical lymphadenectomy is not warranted unless clinically obvious disease is present. As with laryngeal tumors, response to varying chemotherapy regimens has not been well documented for salivary SCNC.

As with their laryngeal counterparts, we have not found immunohistochemistry to be of great value in the diagnostic evaluation of salivary SCNC. The one exception is the frequent presence of punctate perinuclear cytokeratin positivity, a good surrogate marker for neuroendocrine differentiation in small cell neoplasms, and documented in SCNC from other locations. Like Merkel cell tumors of the skin, and unlike pulmonary small cell carcinomas, salivary SCNC express cytokeratin $20(53,54)$, and this feature, coupled with their relatively good prognosis, has led to speculation that these are "salivary Merkel cell tumors." This is an interesting theory, but it does not explain the often-associated glandular differentiation seen focally in SCNC. The cytokeratin 20 positivity is helpful in distinguishing salivary SCNC from a metastasis.

\section{Large Cell Neuroendocrine Carcinoma}

As mentioned above, the recognition of largecell, light-microscopically undifferentiated neoplasms with occult neuroendocrine differentiation arising in the lung is relatively recent. Large cell undifferentiated carcinomas have been described sporadically in the head and neck, including the salivary glands, and it seems highly likely that neuroendocrine differentiation will be demonstrated in some of these tumors.

One good candidate for this group is the so-called sinonasal undifferentiated carcinoma (SNUC; 5559). These tumors are composed of intermediate to large cells without light microscopic evidence of differentiation. Immunohistochemical studies have been limited, but at least some cases have expressed neuron specific enolase (NSE). Others have shown scattered neurosecretory granules on ultrastructural analysis. However, in a more recent review we demonstrated lack of staining in SNUC for chromogranin or synaptophysin (59). Assuming that SNUC is capable of showing at least abortive neuroendocrine differentiation, it fits broadly into the category of large cell neuroendocrine carcinoma, although it should be acknowledged that some examples of SNUC closely approach the cell size of small cell neuroendocrine carcinoma. A similar size spectrum is, of course, well recognized for pulmonary neoplasms.

SNUC are typically large tumors involving the nasal cavity and multiple paranasal sinuses and often extending into the periorbital tissues or the central nervous system (Fig. 6). Unlike olfactory neuroblastoma, their origin is not confined to the cribriform plate and superior portion of the nasal cavity. Because of their often-bulky size, their clinical presentation is similar to that of a high-grade lymphoma arising in this region. Symptoms are typically related to a large mass with local invasion, and include epistaxis, proptosis, cranial nerve deficits, pain and visual anomalies. SNUC occur in a broad age range, from patients in their 3rd decade of life to the very elderly. A possible association with cigarette smoking has been suggested, and nickel exposure has also been noted in SNUC patients.

Microscopically, SNUC consist of sheets or large nests of typically medium-sized cells with large ovoid nuclei and often prominent nucleoli (Fig. 7). The large cell nests often exhibit central, comedolike necrosis. Occasionally, SNUC grow in wide trabeculae or ribbons and may have a vaguely organoid pattern. Mitotic rate is very brisk $(>10$ $\mathrm{MF} / 10 \mathrm{HPF}$ ), and vascular invasion is often extensive. We have encountered occasional SNUC with an overlying mucosal component of dysplasia or carcinoma in situ. SNUC lack the dense lymphoplasmacytic infiltrate typical of lymphoepithelioma, another distinct form of "undifferentiated" carcinoma in the head and neck region. By definition, glandular or squamous differentiation is not present in SNUC.

Immunohistochemically, as noted above, SNUC may show some staining for NSE, but in our experience they have generally lacked staining for most other neuroendocrine markers, including synaptophysin and chromogranin. We have documented focal $\beta$-tubulin positivity in these tumors, again suggesting neuroendocrine differentiation, but this marker is not widely available (55). Significantly, SNUC are strongly cytokeratin positive, and the cell nests lack any peripheral S-100 protein-positive cells, as seen in olfactory neuroblastomas (see below). SNUC have been documented to have a deletion of the retinoblastoma gene (60). We have re- 


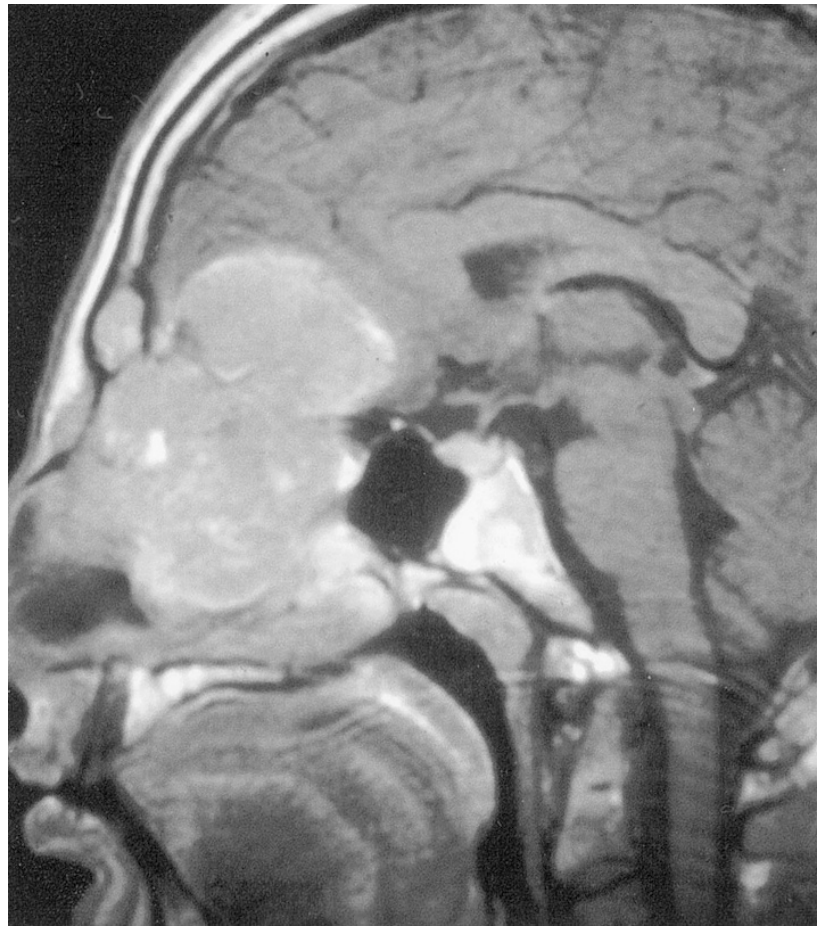

FIGURE 6. This sinonasal undifferentiated carcinoma demonstrates extensive involvement of the nasal cavity and paranasal sinuses with bulky intracranial extension.

cently shown that properly defined SNUC lack Epstein-Barr virus (EBV) RNA (59).

In our recent review of 16 SNUC with followup, 13 patients $(81 \%)$ were dead of disease with a median survival of 18 months (59). Two of the remaining three patients were undergoing treatment of recurrent disease, 7 and 9 months after diagnosis. The remaining patient was the sole disease-free survivor (10-y follow-up). Interestingly, two patients in our series received highdose chemotherapy followed by bone marrow transplantation. Both had long-term disease-free intervals (9 years) but ultimately died of recurrent disease. Because of their dismal clinical behavior, SNUC should be distinguished from olfactory neuroblastoma (ONB), which has a much better prognosis (see below). Some authors have attempted to grade olfactory neuroblastomas based on cytologic pleomorphism. In our experience, most if not all lesions categorized as "Grade IV ONB" are, in reality, SNUC. Unlike ONB, SNUC lack any light-microscopic evidence of neural differentiation including a fibrillary cytoplasmic background, Homer Wright rosettes, or ganglionlike cells. Also aiding in this distinction are the facts that SNUC are strongly cytokeratin positive and lack an S100-protein-positive component at the periphery of cell nests.

SNUC should also be distinguished from nasopharyngeal undifferentiated carcinoma, also known as lymphoepithelioma or lymphepithelial carci-

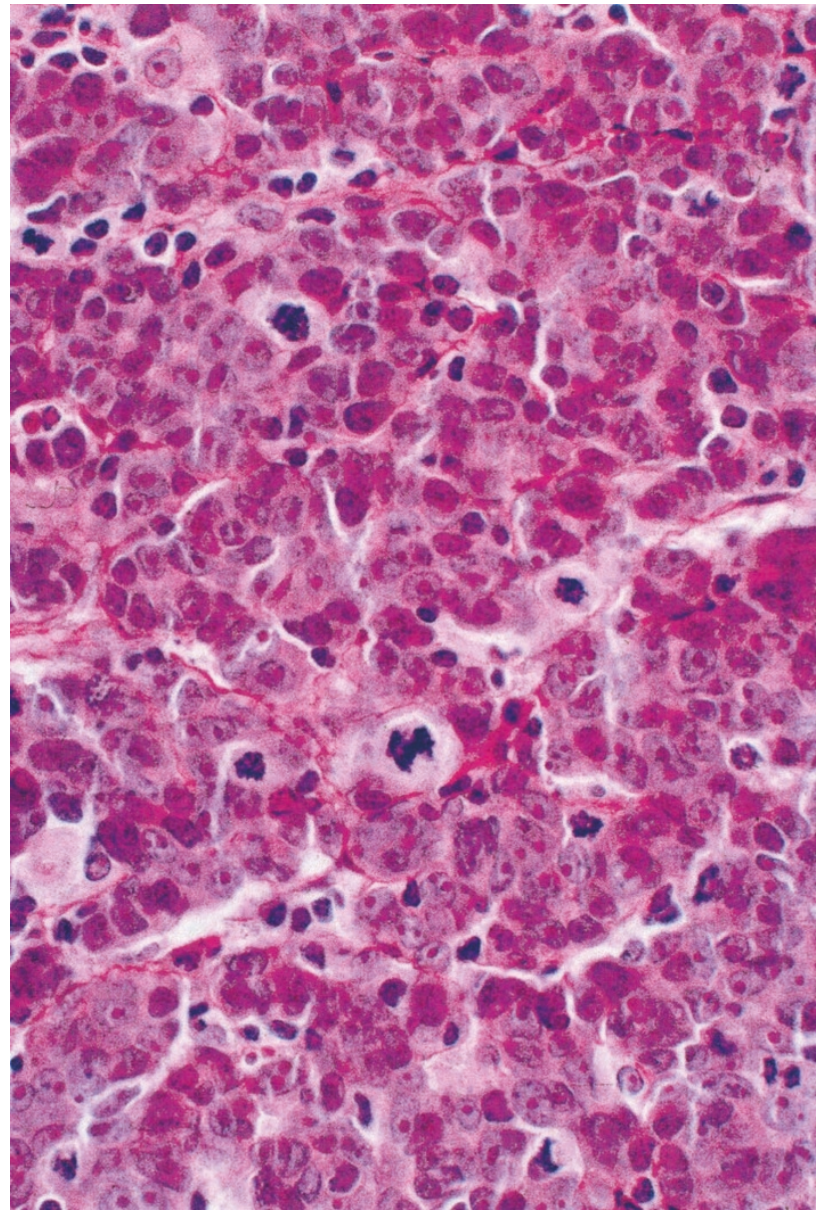

FIGURE 7. Sinonasal undifferentiated carcinoma consists of sheets of moderately sized cells with prominent eosinophilic nucleoli and numerous, often atypical mitotic figures.

noma (LEC). In our experience, SNUC does not arise in the nasopharynx, but bulky lesions may easily extend into this region. Conversely, LEC almost invariably arise in the nasopharynx, but histologically identical lesions may occur in the salivary gland or other "ectopic" sites in the ENT region. Confusion of such LEC with SNUC in the past has led to the erroneous belief that some SNUC were related to EBV (61-64). Again, this is an important distinction because LEC has a better prognosis and is more responsive to radiation therapy than is SNUC.

Distinction of SNUC from LEC can be made on purely morphologic grounds. LEC cells have chromatically uniform, vesicular nuclei with absent or small nucleoli. When LEC forms nests of tumor, the cells typically appear to lack distinct cell borders and form a "syncytium." Although not required for the diagnosis of LEC, the prominent lymphoplasmacytic infiltrate is highly characteristic. In contrast, SNUC cells have prominent nucleoli, distinct cell borders (in good preparations), and lack a lymphoplasmacytic infiltrate. 


\section{DIFFERENTIAL DIAGNOSIS OF ENT NEUROENDOCRINE CARCINOMAS}

\section{Paraganglioma}

The larynx contains two matched sets of normal paraganglia (65-67). These structures are, presumably, the site of origin for true laryngeal paragangliomas. Aberrant or ectopic laryngeal paraganglia have also been described (65). Early studies of laryngeal "paragangliomas" indicated that such tumors appeared to be more frequently malignant than their counterparts occurring elsewhere in the body $(18,19,68-70)$. With time, it became increasingly apparent that many if not all such malignant tumors were, in fact, moderately differentiated neuroendocrine carcinomas (by whatever terminology; $30,33,71)$. It is clear that neuroendocrine carcinomas of the larynx can have a distinctly paraganglioma-like appearance, with cell nests resembling "Zellballen." In a large analysis of the literature regarding laryngeal "paragangliomas," Barnes critically reviewed 78 purported cases (72). Of these, 34 were accepted as paragangliomas. The remaining 44 cases were considered to be "unacceptable." Of the 30 patients with follow-up (mean: $5.2 \mathrm{y}$ ), five developed local recurrences after limited local excisions. Only one of 30 patients (3\%) developed a metastasis. This biologic behavior is quite analogous to that of paragangliomas arising at other locations and emphasizes the need for distinguishing this lesion from more aggressive neuroendocrine carcinomas.

Both paragangliomas and moderately differentiated neuroendocrine carcinomas express neuroendocrine markers, including neuron-specific enolase, chromogranin, and synaptophysin (73). However, the sustentacular cells of paragangliomas will stain strongly for S-100 protein and glial fibrillary acidic protein (73). These cells and this staining are lacking in neuroendocrine carcinomas. In contrast, paragangliomas are cytokeratin negative, whereas this marker is usually positive in moderately differentiated neuroendocrine carcinomas (73). Interestingly, calcitonin has been demonstrated in laryngeal neuroendocrine carcinomas, adding to the potential confusion with metastatic medullary carcinoma (see below), but has not been detected in true laryngeal paragangliomas (73).

\section{Metastatic Medullary Carcinoma}

The histologic similarity of moderately differentiated neuroendocrine carcinoma of the larynx and medullary carcinoma of the thyroid gland has been well described $(10,30,33)$. Wenig et al. (33) noted that the only definitive parameter separating the two lesions was the serum calcitonin level, which is almost invariably elevated in patients with meta- static thyroid carcinoma. Only a single, somewhat controversial laryngeal neuroendocrine carcinoma has been associated with an elevated serum calcitonin level (74).

\section{Malignant Melanoma}

The nesting pattern of moderately differentiated neuroendocrine carcinoma may be confused with the thèques of malignant melanoma. The latter tumors do rarely arise in the larynx $(33,75-79)$. Ultimately, immunohistochemistry may be necessary to resolve this differential possibility. Staining with HMB-45, a highly specific melanocytic marker, is not found in laryngeal neuroendocrine carcinomas (33). Malignant melanomas may also be confused with olfactory neuroblastomas discussed below. Unlike the focal S-100 protein positivity seen predominantly around the periphery of cell nests in olfactory neuroblastomas, sinonasal malignant melanomas usually manifest diffuse reactivity for this marker.

\section{Basaloid Squamous Cell Carcinoma}

These tumors may easily be confused with poorly differentiated neuroendocrine carcinoma of small cell type. When they arise in the larynx, basaloid squamous cell carcinoma (BSCC) have the same marked tendency to involve the supraglottic region seen with neuroendocrine neoplasms (80). Although BSCC are aggressive tumors, primarily because of their advanced stage at presentation, stage for stage their behavior appears to be analogous to that of more conventional squamous cell carcinomas $(80,81)$. BSCC are often confused with small cell carcinomas because of the presence of a prominent, pleomorphic basaloid cell component. More conventional squamous cell carcinoma is invariably present in the basaloid variant. Because of this, the diagnosis of small cell undifferentiated carcinoma with focal squamous differentiation should be approached with considerable caution in areas in which basaloid squamous carcinoma frequently occurs. The presence of overlying squamous dysplasia is strongly supportive of the basaloid variant. Immunohistochemistry is of limited value in making this distinction.

\section{Other Group I Neural Lesions}

Pituitary adenomas may arise ectopically in the upper posterior portion of the nasopharynx (82). More commonly, invasive pituitary lesions may destroy the sella and present as a nasopharyngeal mass (83). The possibility of a pituitary adenoma (invasive or ectopic) should be considered for any upper nasopharyngeal neoplasm with epithelial or neuroendocrine features. Clinicians may be un- 
aware of associated defects in the pituitary sella and almost invariably have not considered this diagnosis.

\section{NEURAL NEOPLASMS (GROUP II)}

\section{Olfactory Neuroblastoma}

Olfactory neuroblastoma (ONB) is the prototypical Group II neural tumor in the head and neck region. Despite its name, ONB has little if anything in common with neuroblastomas elsewhere in the body. The origin of ONB is virtually confined to the olfactory mucosa involving the superior turbinate, cribriform plate, and superior one-third of the nasal septum (Fig. 8). Although there have been rare, apparently "ectopic" ONB arising elsewhere in the sinonasal region or even intracranially, a diagnosis of ONB outside of the upper nasal cavity should be made with the most extreme caution.

ONB arises in a broad age range, with bimodal incidence peaks at approximately 15 and 55 years of age. Presenting symptoms are typically related to nasal obstruction or hemorrhage. On physical examination, it is often possible to visualize a polypoid, vascular-appearing mass high in the nasal cavity. Rarely, patients with ONB have presented with symptoms of ectopic hormone production, in-

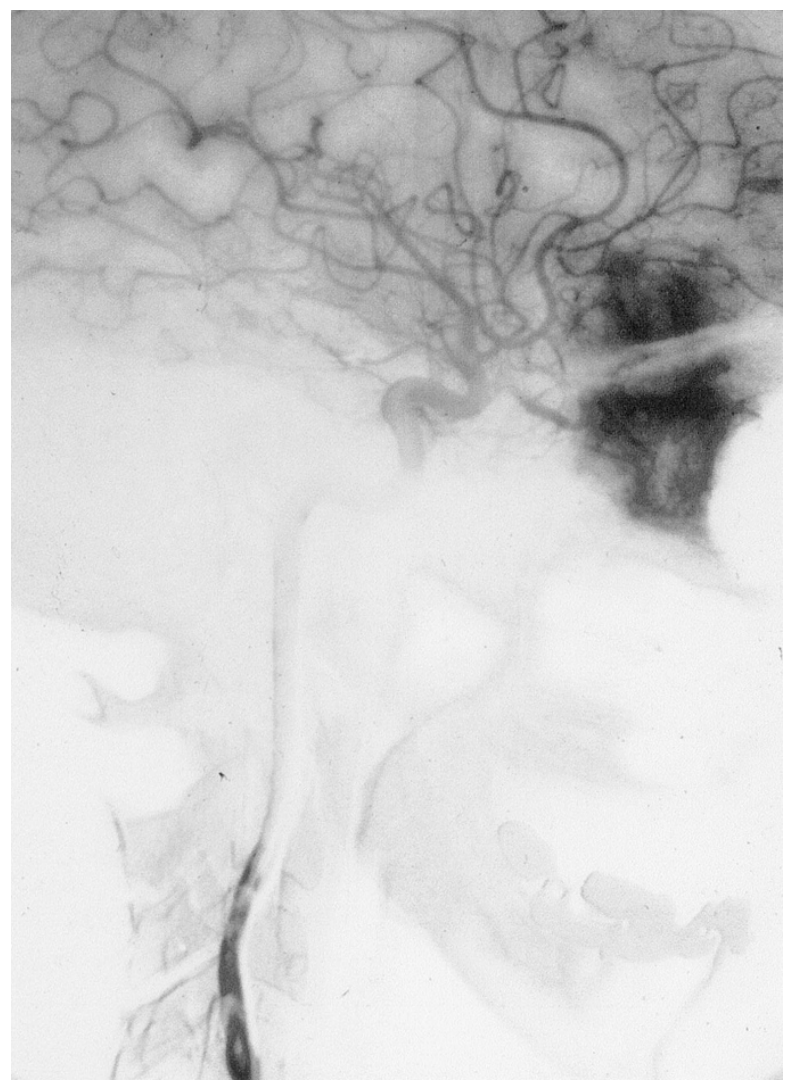

FIGURE 8. As demonstrated in this subtraction angiogram, olfactory neuroblastomas arise in the region of the cribriform plate and may invade it to extend intracranially.

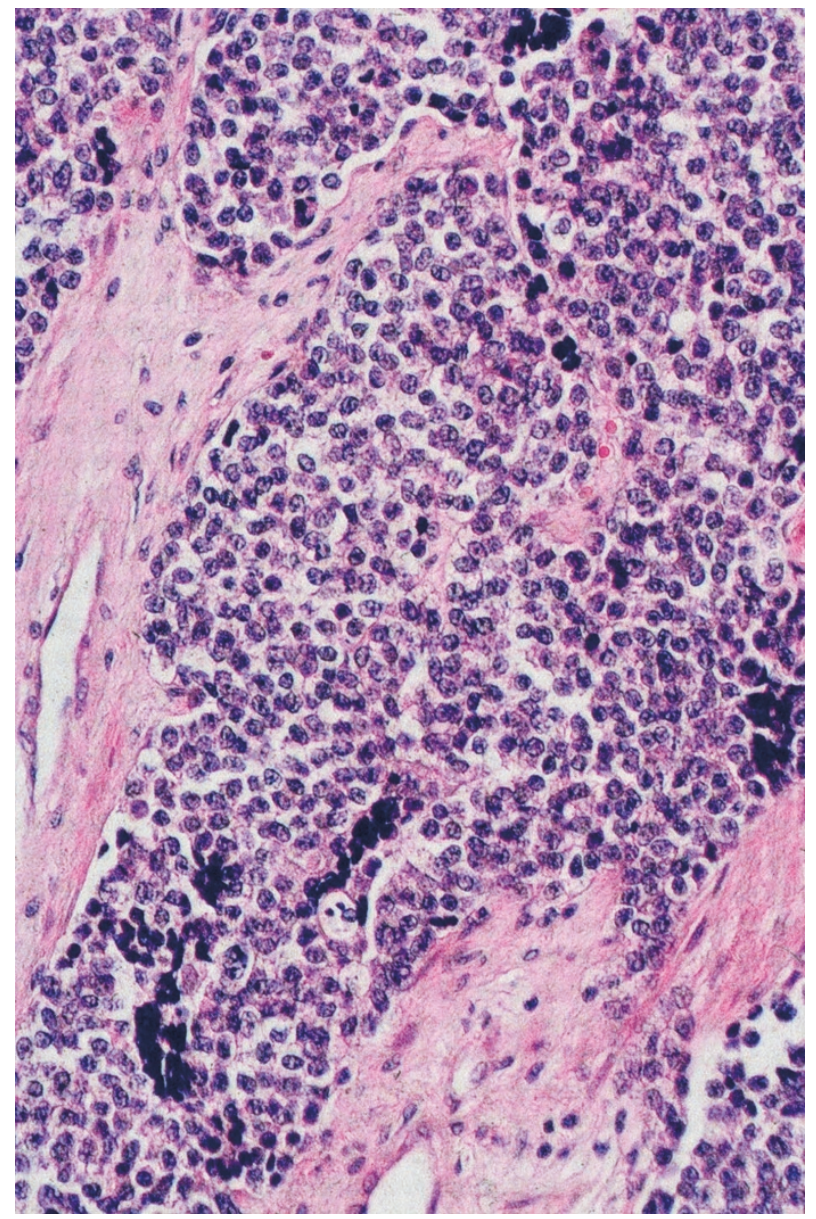

FIGURE 9. Olfactory neuroblastoma forms irregular but sharply demarcated nests of uniform cells with punctate chromatin. Mitotic activity is sparse, but nuclear molding is focally present.

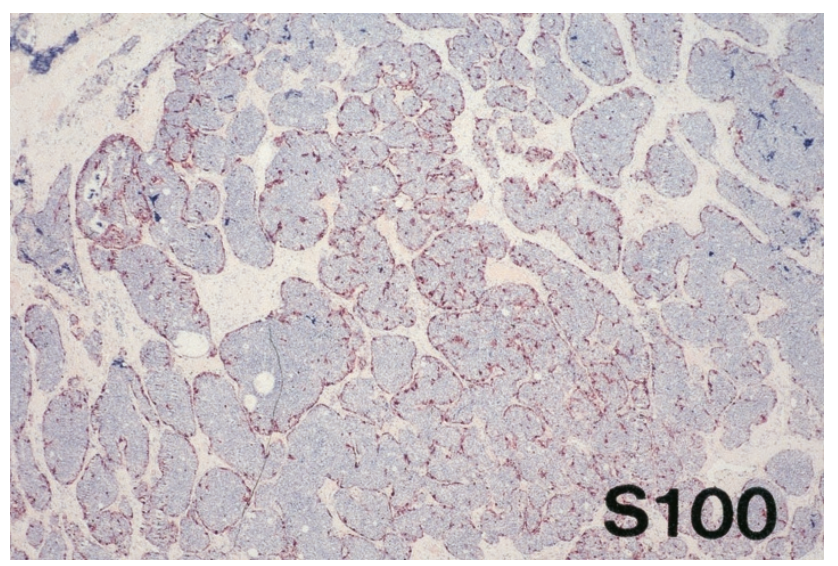

FIGURE 10. When olfactory neuroblastoma forms sharply demarcated nests, the periphery of the nests is often outlined by S100positive cells.

cluding Cushings syndrome secondary to adrenocorticotropic hormone (ACTH) secretion (84) and fluid/electolyte imbalance secondary to antidiuretic hormone (ADH) production (85). Recently, ONB has been shown to have somatostatin receptors and to label with radioactive octreotide, a somatostatin analog. This allows relatively accurate radiologic demonstration of tumor extent (86). 
At low-power magnification, ONB typically exhibits nesting or sheetlike growth (Fig. 9). The neoplastic cells are typically small and round with punctate chromatin, absent or small nucleoli, and minimal cytoplasm. Nuclear pleomorphism is mild or, at most, moderate. Mitotic rate is highly variable, ranging from virtually absent mitotic figures to $>10 / \mathrm{HPF}$. Most often, the mitotic rate is low but apparent. The most helpful morphologic feature is the presence of a fibrillary cytoplasmic background caused by interdigitating neuronal cell processes. In our experience, these can be seen in about $85 \%$ of cases. Less commonly, ONB may exhibit Homer Wright-type rosettes with annular arrays of nuclei surrounding a central fibrillary aggregate. A diffuse fibrillary background is invariably present in such cases, as well. Rarely, ONB may form structures resembling Flexner rosettes, though it has been argued that these are, in reality, foci of glandular differentiation. Ganglion cells may occasionally be encountered in ONB and are also of diagnostic value. Rare ONB may exhibit divergent differentiation in the form of focal glandular, melanocytic, or myogenic cells. The potential for diagnostic confusion is obvious.

Immunohistochemically, the cells of ONB usually demonstrate diffuse positivity for neuron specific enolase and synaptophysin (87-91). Chromogranin is less often positive but occasionally may be strongly so. Scattered S100-positive cells are often present in tumors with a nesting growth pattern and are preferentially located at the periphery of the cell nests (Fig. 10). These cells have Schwannlike ultrastructural features $(87,90-92)$. Their presence should not lead to confusion with malignant melanoma. In fact, we have found these S100 protein-positive cells at the periphery of cell nests to be an extremely helpful diagnostic feature. Because ONB may also show aberrant melanocytic differentiation, they may exhibit focal melanin pigmentation or even focal staining for HMB-45 (88). As noted above, the potential for confusion with malignant melanoma is obvious. Unlike "classic" Group II neuroendocrine neoplasms, up to one third of ONB will exhibit at least focal staining for low molecular weight cytokeratin $(87,93)$. This may occur in areas of obvious aberrant glandular or epithelial differentiation or in otherwise lightmicroscopically typical ONB cells. Staining for EMA is negative $(91,93)$.

Complete surgical resection is the treatment of choice for ONB. Because of the tumor's location and tendency to penetrate the cribriform plate, this may require a combined craniofacial resection. Despite the extensive nature of this procedure, other than anosmia, the resultant functional and cosmetic deficits are minimal. Complete surgical resection, often followed by supplemental radiation or chemotherapy, results in a 5-year cure rate of approximately $75 \%$ (94). Although counterintuitive for a tumor with blastoma in its name, 5-year disease-free survivals should not be equated with cure. Recurrences have been noted to develop after disease-free intervals of more than 10 years. Among patients with recurrent disease, about two thirds have local recurrence, about one quarter develop regional nodal involvement, and about $15 \%$ experience distant disease.

With the widespread emergence of molecular diagnostic techniques applicable to paraffinembedded tissue, it was initially suggested that ONB was a form of peripheral neuroectodermal tumor (PNET), based on the apparent finding of the $\mathrm{t}(11 ; 22)(\mathrm{q} 24 ; \mathrm{q} 12)$ translocation characteristic of Ewing's sarcoma and PNET in some ONB (95). However, a more recent study performing RT-PCR on 11 ONBs failed to find the chimeric EWS/FLI1 transcript in any of these tumors (96). Southern blot analysis also showed no evidence of the EWS gene rearrangement. These findings explain the demonstrated absence of CD99 immunohistochemical reactivity in ONB (96-98).

\section{Sinonasal Malignant Melanoma}

The mucosal surfaces of the sinonasal region account for about $1 \%$ of all malignant melanomas (99-103). Patients with sinonasal malignant melanomas are typically 50 years of age or older, although rare examples have been described in children. In decreasing order of frequency, the tumors favor the nasal cavity, maxillary antrum, ethmoid sinuses, and sphenoid sinus. Significantly, nasal lesions favor the anterior nasal cavity and middle or lower turbinates. These tumors rarely if ever involve the nasopharynx or olfactory mucosa higher in the nasal cavity. Other well-documented sites for mucosal melanomas of the head and neck include the oral cavity and the larynx.

Mucosal malignant melanomas are aggressive neoplasms. Radiation therapy and chemotherapy have been of little or no value in their treatment (104). Median survival is approximately 18 months. Depth of invasion has not convincingly been correlated with prognosis. The role of adjuvant immunotherapy is under active investigation.

Distinction of malignant melanoma from other less aggressive and more therapeutically amenable tumors is obviously important. Diffuse staining for S100 protein, staining with HMB-45, or newer markers such as anti-tyrosinase may be very helpful diagnostically. Scattered S100-positive cells may be seen in ONB and in a variety of carcinomas, so this marker must be interpreted with some care. In general, considering a diagnosis of malignant melanoma for any high-grade, sinonasal neoplasm with- 


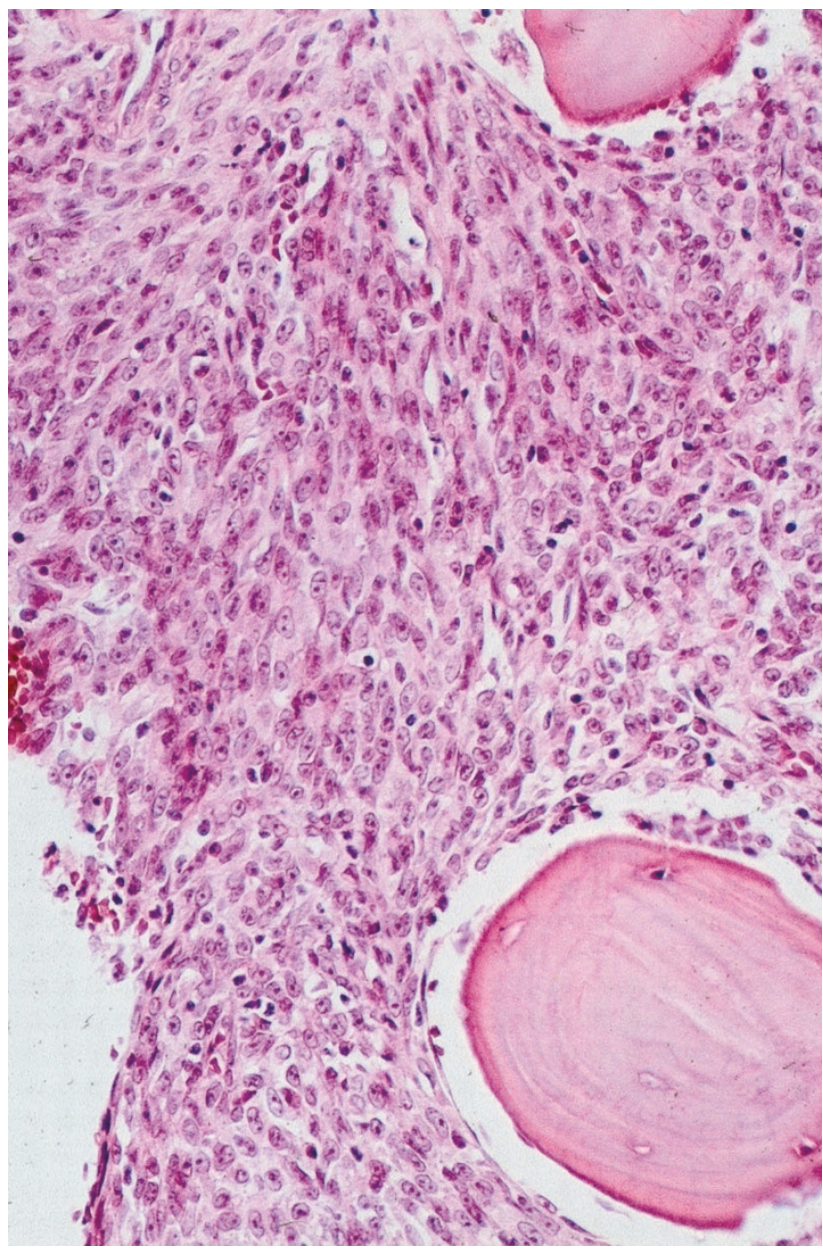

FIGURE 11. Sinonasal malignant melanomas may be composed of distinctly spindled cells as in this example, which is invading cranial bone.

out overt epithelial differentiation is a good approach. This should lead to appropriate additional studies to confirm or refute the diagnosis.

Mucosal malignant melanomas can exhibit a wide variety of histologic appearances. They may be composed of small round cells mimicking lymphoma or small cell carcinoma, epithelioid cells resembling large cell undifferentiated carcinoma, rhabdoid cells resembling a rhabdoid tumor, or spindled cells mimicking a variety of sarcomas (99) (Fig. 11). In our experience, the distinction between ONB and malignant melanoma can be particularly problematic and is particularly important clinically. As noted above, location can be extremely helpful if reliable information is available.

Rarely, mucosal melanomas may exhibit a distinctly fibrillar background of the type typically seen with ONB. Poorly formed Homer Wright rosettes may even be identified. Conversely, focal melanin pigment may be found in ONB (105). Strong diffuse staining for S100 protein or with HMB-45 should allow distinction. It should be noted that to further complicate matters, rare

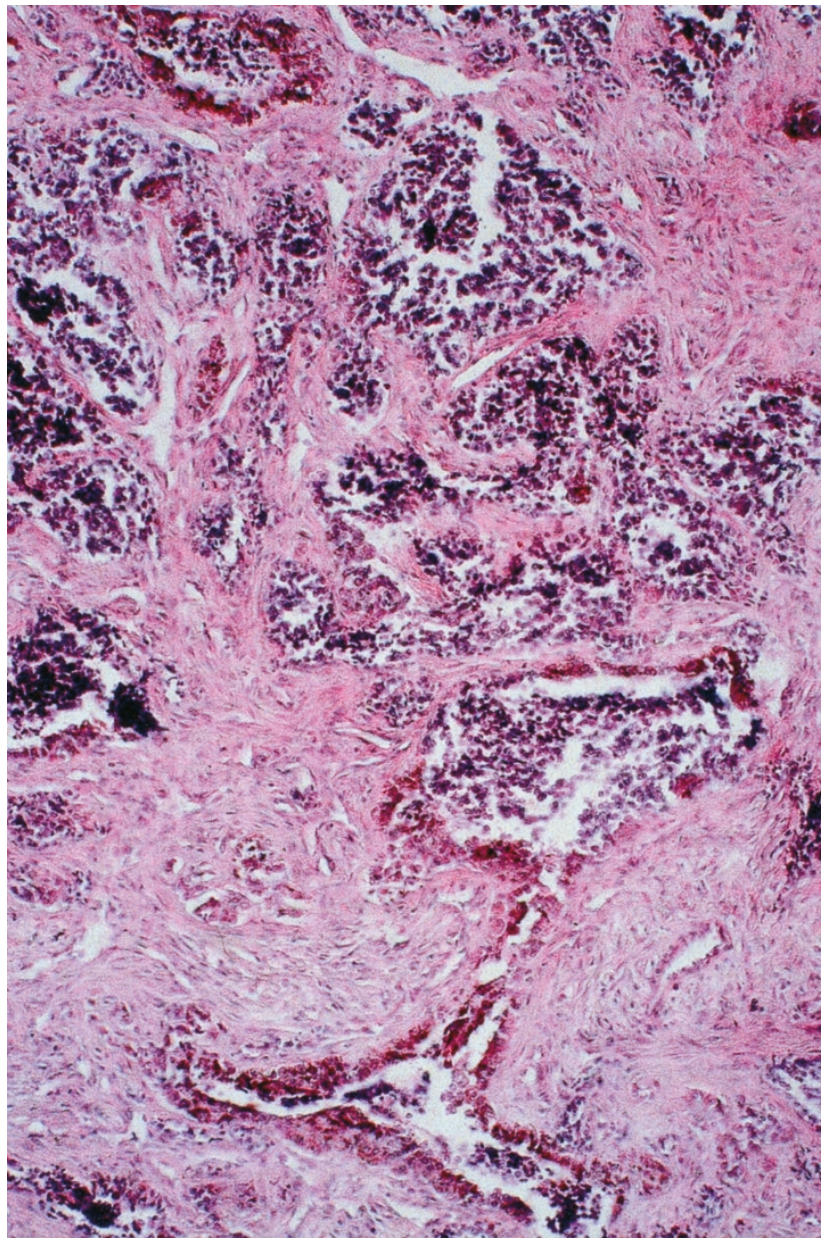

FIGURE 12. Melanotic neuroectodermal tumor of infancy consists of alveolar nests of neuroblastlike cells in a densely fibrotic stroma. Larger pigmented cells also present in these lesions are not readily visible at this magnification.

HMB-45-positive cells have been seen in ONB with some melanocytic differentiation. Such tumors are fortunately extremely rare and only focally positive.

\section{Ewing's Sarcoma/PNET}

Approximately 9\% of extraosseous Ewing's sarcomas (EOE) arise in the upper aerodigestive tract or head and neck region, making it the third most common anatomic site, after the extremities and the thoracic/abdominal region (106-109). Patients are typically children or adolescents (mean age: $18 \mathrm{y})$, though EOE have been described in elderly individuals.

More than $90 \%$ of EOE will label strongly with antibodies directed against the MIC-2 protein product created by the $t(11: 22)$ fusion of the EWS/FLI-1 genes (110). This marker is of considerable diagnostic value, but it is by no means specific. Many lymphomas, particularly lymphoblastic and T-cell lymphomas, express the MIC-2 protein. In addition, a growing number of other neoplasms is being documented as expressing this protein. We recently 
documented this protein in an otherwise typical SNUC $(59,111)$.

\section{Melanotic Neuroectodermal Tumor of Infancy}

Although extremely rare, the striking predilection of this tumor for the head and neck merits its brief mention. Melanotic neuroectodermal tumor of infancy (MNTI) are polyphenotypic neoplasms exhibiting evidence of neural, epithelial, mesenchymal, and neuroectodermal differentiation. As such, they do not fit well into the Class I/II designation for neuroectodermal neoplasia discussed above. MNTI are often present at birth and invariably develop in infants under 1 year of age. About $70 \%$ involve the anterior maxilla, with most of the remainder occurring elsewhere in the head and neck, including mandible, and other skull bones (112).

Microscopically, MNTI consist of a biphasic population of large and small cells forming alveolar or tubular-like structures embedded in a fibrotic stroma (Fig. 12). The small cells resemble neuroblasts and the larger cells often contain prominent cytoplasmic melanin pigment. Nuclear pleomorphism, mitotic activity, and necrosis are only rarely noted. Immunohistochemically, the larger cells of MNTI are typically positive for cytokeratin, vimentin, and with HMB-45. Staining for EMA in the large cells is variable. Both the small and large cell populations are usually positive for NSE and may also react for Leu-7 or with muscle markers. Staining for synaptophysin and glial fibrillary acid protein has also been described (113).

Simple excision with free margins is curative in almost all cases. About $15 \%$ local recurrence and $6 \%$ metastasis, usually to regional lymph nodes, has been reported, but probably represents over reporting of atypical cases. Because of their usually benign biologic behavior, MNTI must be distinguished from small cell malignancies that occur in childhood, including metastatic neuroblastoma, primitive PNET, and rhabdomyosarcoma. Awareness of this rare lesion and its highly characteristic microscopic appearance usually allows recognition. However, the alveolar growth pattern and presence of myogenous markers in some MNTI may cause confusion with rhabdomyosarcoma. The presence of melanin pigment, biphasic cell population, and strong cytokeratin positivity should allow distinction.

\section{Other Group II Neural Lesions}

A considerable number of additional Group II neuroectodermal lesions may occur in the head and neck. These lesions are not reviewed here, either because of their lack of a strong predilection to involve this region or because they are quite un- common. This list of unreviewed lesions includes heterotopic glial tissue ("nasal glioma"), neuromas of varying types, neurofibroma, schwannoma, nerve sheath myxoma, granular cell tumor, "congenital epulis," meningioma, and, of course, paraganglioma.

\section{REFERENCES}

1. Ferlito A. The World Health Organization's revised classification of tumours of the larynx, hypopharynx, and trachea. Ann Otol Rhinol Laryngol 1993;102:666-9.

2. Beasley MB, Thunnissen FBJM, Brambilla E, Hasleton P, Steele R, Hammar SP, et al. Pulmonary atypical carcinoid: predictors of survival in 106 cases. Hum Pathol 2001;31: 1255-65.

3. Travis WD, Rush W, Flieder DB, Falk R, Fleming MV, Gal AA, et al. Survival analysis for 200 pulmonary neuroendocrine tumors with clarification of criteria for atypical carcinoid and its separation from typical carcinoid. Am J Surg Pathol 1998;22:934-44.

4. Travis WD, Linnoila RI, Tsokos MG, Hitchcock CL, Cutler GB, Nieman L, et al. Neuroendocrine tumors of the lung with proposed criteria for large-cell neuroendocrine carcinoma. An ultrastructural, immunohistochemical and flow cytometric study of 35 cases. Am J Surg Pathol 1991;15:529 33.

5. Goldman NC, Hood CI, Singleton GT. Carcinoid of the larynx. Arch Otolaryngol 1969;90:90-3.

6. Snyderman C, Johnson JT, Barnes L. Carcinoid tumor of the larynx: case report and review of the world literature. Otolaryngol Head Neck Surg 1986;95:158-64.

7. Markel SF, Magielski JE, Beals TF. Carcinoid tumor of the larynx. Arch Otolaryngol 1980;106:777-8.

8. Gapany-Gapanavicius B, Kenan S. Carcinoid tumor of the larynx. Ann Otol 1981;90:42-7.

9. Dictor M, Tennvall J, Åkerman M. Moderately differentiated neuroendocrine carcinoma (atypical carcinoid) of the supraglottic larynx. A report of two cases including immunohistochemistry and aspiration cytology. Arch Pathol Lab Med 1992;116:253-7.

10. El-Naggar AK, Batsakis JG, Vasilopoulou-Sellin R, Ordóñez NG, Luna MA. Medullary (thyroid) carcinoma-like carcinoids of the larynx. J Laryngol Otol 1991;105:683-6.

11. Mills SE, Johns ME. Atypical carcinoid tumor of the larynx: a light microscopic and ultrastructural study. Arch Otolaryngol 1984;110:58-62.

12. Tamai S, Iri H, Maruyama $T$, Kasahara M, Akatsuka S, Sakurai S, et al. Laryngeal carcinoid tumor. Light and electron microscopic studies. Cancer 1981;48:2256-9.

13. Googe PB, Ferry JA, Bhan AK, Dickersin GR, Pilch BZ, Goodman M. A comparison of paraganglioma, carcinoid tumor, and small-cell carcinoma of the larynx. Arch Pathol Lab Med 1988;112:809-15.

14. Porto DP, Wick MR, Ewing SL, Adams GL. Neuroendocrine carcinoma of the larynx. Am J Otolaryngol 1987;9:97-104.

15. Capper JW, Michaels L, Gregor RT. A malignant carcinoid tumor of the supraglottic larynx. J Laryngol Otol 1981;95: 963-71.

16. Cefis F, Cattaneo M, Ricci PMC, Frigerio B, Usellini L, Capella C. Primary polypeptide hormones and mucin producing malignant carcinoid of the larynx. Ultrastruct Pathol 1983;5:45-53.

17. Stanley RJ, Weiland LH, Neel B. Pain-inducing laryngeal paraganglioma: report of the ninth case and review of the literature. Otolaryngol Head Neck Surg 1986;95:107-12.

18. Marks PV, Brookes GB. Malignant paraganglioma of the larynx. J Laryngol Otol 1983;97:1183-8. 
19. Ali S, Aird DW, Bihari J. Pain-inducing laryngeal paragangliomas (non-chromaffin). J Laryngol Otol 1983;97:181-8.

20. Goldman NC, Katibah GM, Mechina J. Carcinoid tumors of the larynx. Ear Nose Throat J 1985;64:52-8.

21. Blok PH, Manni JJ, van den Brock P, van Haelst UJ, Slooff JL. Carcinoid of the larynx: a report of three cases and a review of the literature. Laryngoscope 1985;95:715-9.

22. Patterson SD, Yarrington CT. Carcinoid tumor of the larynx: the role of conservative therapy. Ann Otol Rhinol Laryngol 1987;96:12-4.

23. Baugh RF, Wolf GT, Lloyd RV, McClatchey KD, Evans D. Carcinoid (neuroendocrine carcinoma) of the larynx. Ann Otol Rhinol Laryngol 1987;96:315-21.

24. El-Naggar AK, Batsakis JG. Carcinoid tumor of the larynx. A critical review of the literature. ORL J Otorhinolaryngol Relat Spec 1991;53:188-93.

25. Stanley MW, Horwitz CA, Levinson RM, Sibley RK. Carcinoid tumors of the middle ear. Am J Clin Pathol 1987;87: 592-600.

26. Mills SE, Fechner RE. Middle ear adenoma: a cytologically uniform neoplasm displaying a variety of architectural patterns. Am J Surg Pathol 1984;8:677-85.

27. Wassef M, Kanavaros P, Polivka M, Nemeth J, Monteil J-P, Frachet B, et al. Middle ear adenoma. A tumor displaying mucinous and neuroendocrine differentiation. Am J Surg Pathol 1989;13:838-47.

28. Murphy GF, Pilch BZ, Dickersin GR, Goodman ML. Carcinoid tumor of the middle ear. Am J Clin Pathol 1980;73: 816-23.

29. McNutt MA, Bolen JW. Adenomatous tumor of the middle ear. Am J Clin Pathol 1985;84:541-7.

30. Woodruff JM, Huvos AG, Erlandson RA, Shah JP, Gerold FP. Neuroendocrine carcinomas of the larynx. A study of two types, one of which mimics thyroid medullary carcinoma. Am J Surg Pathol 1985;9:771-90.

31. Ferlito A, Barnes L, Rinaldo A, et al. A review of neuroendocrine neoplasms of the larynx: update on diagnosis and treatment. J Laryngol Otol 1998;112:827-34.

32. Wenig BM, Gnepp DR. The spectrum of neuroendocrine carcinomas of the larynx. Semin Diagn Pathol 1989;6:329 50.

33. Wenig BM, Hyams VJ, Heffner DK. Moderately differentiated neuroendocrine carcinoma of the larynx. A clinicopathologic study of 54 cases. Cancer 1988;62:2658-76.

34. Woodruff JM, Senie RT. Atypical carcinoid tumor of the larynx. A critical review of the literature. ORL J Otorhinolaryngol Relat Spec 1991;53:194-209.

35. Gnepp DR, Ferlito A, Hyams V. Primary anaplastic small cell (oat cell) carcinoma of the larynx. Review of the literature and report of 18 cases. Cancer 1983;51:1731-45.

36. Mills SE, Cooper PH, Garland TA, Johns ME. Small cell undifferentiated carcinoma of the larynx. Report of two patients and review of 13 additional cases. Cancer 1983;51: 116-20.

37. Ferlito A. Oat cell carcinoma of the larynx. Ann Otol 1974; 83:254-6.

38. Benisch BM, Tawfik B, Breitenbach EE. Primary oat cell carcinoma of the larynx: an ultrastructural study. Cancer 1975;36:145-8.

39. Mullins JD, Newman RK, Coltman CA Jr. Primary oat cell carcinoma of the larynx. A case report and review of the literature. Cancer 1979;43:711-7.

40. Kyriakos M, Berlin BP, DeSchryver-Kecskemeti K. Oat-cell carcinoma of the larynx. Arch Otolaryngol 1978;104:168-76.

41. Gelot R, Rhee TR, Lapidot A. Primary oat-cell carcinoma of head and neck. Ann Otol 1975;84:238-44.

42. Bitran JD, Toledo-Pereyra LH, Matz G. Oat cell carcinoma of the larynx. Response to combined modality therapy. Cancer 1978;42:85-7.
43. Bone RC, Deer D. Oat cell carcinoma of the larynx. Laryngoscope 1978;88:1190-5.

44. Myerowitz RL, Barnes EL, Myers E. Small cell anaplastic (oat cell) carcinoma of the larynx: report of a case and review of the literature. Laryngoscope 1978;88:1697-702.

45. Johnson GD, Mahataphongse VP, Abt AB, Conner GH. Small cell undifferentiated carcinoma of the larynx. Ann Otol 1979;88:774-8.

46. Sun CJ, Hall-Craggs M, Adler B. Oat cell carcinoma of larynx. Arch Otolaryngol 1981;107:506-9.

47. Olofsson J, van Nostrand AWP. Anaplastic small cell carcinoma of larynx. Case report. Ann Otol 1972;81:284-7.

48. Chen DA, Mandell-Brown M, Moore SF, Johnson JT. "Composite" tumor-mixed squamous cell carcinoma and small cell anaplastic carcinoma of the larynx. Otolaryngol Head Neck Surg 1986;95:99-103.

49. Gnepp DR. Small cell neuroendocrine carcinoma of the larynx. A critical review of the literature. ORL J Otorhinolaryngol Relat Spec 1991;53:210-9.

50. Bishop JW, Osamura RY, Tsutsumi Y. Multiple hormone production in an oat cell carcinoma of the larynx. Acta Pathol Jpn 1985;35:915-23.

51. Soussi AC, Benghiat A, Holgate CS, Majumdar B. Neuroendocrine tumors of the head and neck. J Laryngol Otol 1990; 104:504-7.

52. Gnepp DR, Corio RL, Brannon RB. Small cell carcinoma of the major salivary glands. Cancer 1986;60:1583-8.

53. Cheuk W, Kwan MY, Suster S, Chan JK. Immunostaining for thyroid transcription factor 1 and cytokeratin 20 aids the distinction of small cell carcinoma from Merkel cell carcinoma, but not pulmonary from extrapulmonary small cell carcinomas. Arch Pathol Lab Med 2001;125(2):228-31.

54. Nicholson SA, McDermott MB, Swanson PE, Wick MR. CD99 and cytokeratin-20 in small-cell and basaloid tumors of the skin. Appl Immunohistochem Mol Morphol 2000; $8(1): 37-41$.

55. Frierson HF Jr, Mills SE, Fechner RE, Taxy JB, Levine PA. Sinonasal undifferentiated carcinoma. An aggressive neoplasm derived from Schneiderian epithelium and distinct from olfactory neuroblastoma. Am J Surg Pathol 1986;10: 771-9.

56. Helliwell TR, Yeoh LH, Stell PM. Anaplastic carcinoma of the nose and paranasal sinuses. Light microscopy, immunohistochemistry, and clinical correlation. Cancer 1986;58: $2038-45$.

57. Stewart FM, Lazarus HM, Levine PA, Stewart KA, Tabbara IA, Spaulding CA. High-dose chemotherapy and autologous marrow transplantation for esthesioneuroblastoma and sinonasal undifferentiated carcinoma. Am J Clin Oncol 1989; $12: 217-21$.

58. Levine PA, Frierson HF Jr, Stewart FM, Mills SE, Fechner RE, Cantrell RW. Sinonasal undifferentiated carcinoma: a distinctive and highly aggressive neoplasm. Laryngoscope 1987;97:905-8.

59. Cerilli LA, Holst VA, Brandwein MS, Stoler MH, Mills SE. Sinonasal undifferentiated carcinoma. Immunohistochemical profile and lack of EBV association. Am J Surg Pathol 2001;25:156-163.

60. Greger V, Schirmacher P, Bohl J, Bornemann A, Hürter T, Passarge E, et al. Possible involvement of the retinoblastoma gene in undifferentiated sinonasal carcinoma. Cancer 1990;66:1954-9.

61. Lopategui JR, Gaffey MJ, Frierson HF Jr, Chan JKC, Mills SE, Chang KL, et al. Detection of Epstein-Barr viral RNA in sinonasal undifferentiated carcinoma from Western and Asian patients. Am J Surg Pathol 1994;18:391-8.

62. Leung SY, Yuen ST, Chung LP, Kwong WK, Wong MP, Chan SY. Epstein-Barr virus is present in a wide histological spec- 
trum of sinonasal carcinomas. Am J Surg Pathol 1995;11: 994-1001.

63. Gallo O, Di Lollo S, Graziani P, Gallina E, Baroni G. Detection of Epstein-Barr virus genome in sinonasal undifferentiated carcinoma by use of in situ hybridization. Otolaryngol Head Neck Surg 1995;112(6):659-64.

64. Hwang TZ, Jin YT, Tsai ST. EBER in situ hybridization differentiates carcinomas originating from the sinonasal region and the nasopharynx. Anticancer Res 1998;18(6B): 4581-4.

65. Lawson W, Zak FG. The glomus bodies ("paraganglia") of the human larynx. Laryngoscope 1974;84: 98-111.

66. Watska MA. Uber die paraganglien in der plica ventricularis des menschlichen kehlkopfes. Dtsch Med Forsch 1963;1: $19-20$.

67. Kleinsasser O. Das glomus laryngicum inferior. Arch Ohrenheilk 1964;184:214-24.

68. Wetmore RF, Tronzo RD, Lane RJ, Lowry LD. Nonfunctional paraganglioma of the larynx: clinical and pathological considerations. Cancer 1981;48:2717-23.

69. Sneige N, Mackay B, Ordóñez NG, Batsakis JG. Laryngeal paraganglioma. Report of two tumors with immunohistochemical and ultrastructural analysis. Arch Otolaryngol 1983;109:113-7.

70. Vetters JM, Toner PG. Chemodectoma of larynx. J Pathol 1970;101:259-65.

71. Spagnolo DV, Paradinas FJ. Laryngeal neuroendocrine tumour with features of a paraganglioma, intracytoplasmic lumina and acinar formation. Histopathology 1985;9:11731.

72. Barnes L. Paraganglioma of the larynx. A critical review of the literature. ORL J Otorhinolaryngol Relat Spec 1991;53: 220-34.

73. Milroy CM, Rode J, Moss E. Laryngeal paragangliomas and neuroendocrine carcinomas. Histopathology 1991;18:201-9.

74. Sweeney EC, McDonnell L, O'Brien C. Medullary carcinoma of the thyroid presenting as tumors of the pharynx and larynx. Histopathology 1981;5:263-75.

75. Reuter VE, Woodruff JM. Melanoma of the larynx. Laryngoscope 1986;94:389-93.

76. Pantazopoulos PE. Primary malignant melanoma of the larynx. Laryngoscope 1964;74:95-102.

77. Curtiss C, Kosinski AA. Primary malignant melanoma of the larynx: report of a case and review of the literature. Cancer 1955;8:961-3.

78. Loughead JR. Malignant melanoma of the larynx. Ann Otol Rhinol Laryngol 1952;61:154-8.

79. Fisher GE, Odess JS. Metastatic malignant melanoma of the larynx. Arch Otolaryngol 1951;54:639-42.

80. Banks ER, Frierson HF Jr, Mills SE, George E, Zarbo RJ, Swanson PE. Basaloid squamous cell carcinoma of the head and neck. A clinicopathologic and immunohistochemical study of 40 cases. Am J Surg Pathol 1992;16:939-46.

81. Paulino AF, Singh B, Shah JP, Huvos AG. Basaloid squamous cell carcinoma of the head and neck. Laryngoscope 2000;110(9):1479-82.

82. Lloyd RV, Chandler WF, Kovacs K, Ryan N. Ectopic pituitary adenomas with normal anterior pituitary glands. Am J Surg Pathol 1986;10(8):546-52.

83. Gandour-Edwards R, Kapadia SB, Janecka IP, Martinez AJ, Barnes L. Biologic markers of invasive pituitary adenomas involving the sphenoid sinus. Mod Pathol 1995;8(2):160-4.

84. Arnesen MA, Scheithauer BW, Freeman S. Cushing's syndrome secondary to olfactory neuroblastoma. Ultrastruct Pathol 1994;18:61-8.

85. Myers SL, Hardy DA, Wiebe CB, Shiffman J. Olfactory neuroblastoma invading the oral cavity in a patient with inappropriate antidiuretic hormone secretion. Oral Surg Oral Med Oral Pathol 1994;77:645-50.
86. Ramsay HA, Kairemo KJ, Jekunen AP. Somatostatin receptor imaging of olfactory neuroblastoma. J Laryngol Otol 1996;110:1161-3.

87. Frierson HF Jr, Ross GW, Mills SE, Frankfurter A. Olfactory neuroblastoma. Additional immunohistochemical characterization. Am J Clin Pathol 1990;94:547-53.

88. Wick MR, Stanley SJ, Swanson PE. Immunohistochemical diagnosis of sinonasal melanoma, carcinoma, and neuroblastoma with monoclonal antibodies HMB-45 and antisynaptophysin. Arch Pathol Lab Med 1988;112:616-20.

89. Lund VJ, Milroy C. Olfactory neuroblastoma: clinical and pathological aspects. Rhinology 1993;31:1-6.

90. Taxy JB, Hidvegi DF. Olfactory neuroblastoma. An ultrastructural study. Cancer 1977;39:131-8.

91. Axe S, Kuhajda FP. Esthesioneuroblastoma. Intermediate filaments, neuroendocrine, and tissue-specific antigens. Am J Clin Pathol 1987;88:139-45.

92. Choi HS, Anderson PJ. Olfactory neuroblastoma: an immuno-electron microscopic study of S-100 protein-positive cells. J Neuropathol Exp Neurol 1986;45: 576-87.

93. Taxy JB, Bharani NK, Mills SE, Frierson HF Jr, Gould VE. The spectrum of olfactory neural tumors. A lightmicroscopic, immunohistochemical and ultrastructural analysis. Am J Surg Pathol 1986;10:687-95.

94. Eden BV, Debo RF, Larner JM, Kelly MD, Levine PA, Stewart FM, et al. Esthesioneuroblastoma. Long term outcome and patterns of failure-the University of Virginia experience. Cancer 1994;73:2556-62.

95. Sorensen PH, Wu JK, Berean KW. Olfactory neuroblastoma is a peripheral primitive neuroectodermal tumor related to Ewing sarcoma. Proc Natl Acad Sci U S A 1996;93:1038-43.

96. Argani P, Perez-Ordonez B, Xiao H, Caruana SM, Huvos AG, Ladanyi M. Olfactory neuroblastoma is not related to the Ewing family of tumors. Absence of EWS/FLI1 gene fusion and MIC2 expression. Am J Surg Pathol 1998;22: 391-8.

97. Nelson RS, Perlman EJ, Askin FB. Is esthesioneuroblastoma a peripheral neuroectodermal tumor? Hum Pathol 1995;26: 639-41.

98. Devaney K, Wenig BL, Abbondanzo SL. Olfactory neuroblastoma and other round cell tumors of the sinonasal region. Mod Pathol 1996;9:658-63.

99. Franquemont DW, Mills SE. Sinonasal malignant melanoma. A clinicopathologic and immunohistochemical study of 14 cases. Am J Clin Pathol 1991;96:689-97.

100. Blatchford SJ, Koopman CF, Coulthard SW. Mucosal melanoma of the head and neck. Laryngoscope 1986;96:92934.

101. Bittesini L, Deitos AP, Fletcher CDM. Metastatic melanoma showing a rhabdoid phenotype. Histopathology 1992;20: 167-70.

102. Cove H. Melanosis, melanocytic hyperplasia, and primary malignant melanoma of the nasal cavity. Cancer 1994;44: 1424-33.

103. Fritsch MH, Hanke CW, Kaiafas D. Malignant melanoma of the head and neck. Otolaryngol Head Neck Surg 1994;110: 356-7.

104. Lund VJ, Howard DJ, Harding L, Wei WI. Management options and survival in malignant melanoma of the sinonasal mucosa. Laryngoscope 1999;109(2 Pt 1):208-11.

105. Curtis JL, Rubinstein LJ. Pigmented olfactory neuroblastoma. A new example of melanotic neuroepithelial neoplasm. Cancer 1982;49:2136-43.

106. Cavazzana AO, Ninfo V, Roberts J, Triche TJ. Peripheral neuroepithelioma: a light microscopic, immunocytochemical, and ultrastructural study. Mod Pathol 1992;5: $71-8$. 
107. Jurgens H, Bier V, Harms D, et al. Malignant peripheral neuroectodermal tumors: a retrospective analysis of $42 \mathrm{pa}-$ tients. Cancer 1988;61:349-57.

108. Shimada H, Newton WA, Soule EH, Qualman SJ, Aoyama C, Maurer HM. Pathologic features of extraosseous Ewing's sarcoma: a report from the intergroup rhabdomyosarcoma study. Hum Pathol 1988;19:442-53.

109. Swanson PE, Humphrey PA, Dehner LP. Immunoreactivity for bcl-2 protein in peripheral primitive neuroectodermal tumors. Appl Immunohistochem 1993;1:182-7.

110. Weidner N, Tjoe J. Immunohistochemical profile of monoclonal antibody O13: antibody that recognizes glycoprotein p30/32MIC2 and is useful in diagnosing Ewing's sarcoma and peripheral neuroepithelioma. Am J Surg Pathol 1994; 18:486-94.

111. Chen KTK, Ma CK, Nelson JW, Padmanabhan A, Brittin GM. Clear cell myeloma. Am J Surg Pathol 1985;9:149-54.

112. Pettinato G, Manivel JC, d'Amore ESG, Jaszcz W, Gorlin RJ. Melanotic neuroectodermal tumor of infancy. A reexamination of a histogenetic problem based on immunohistochemical, flow cytometric, and ultrastructural study of 10 cases. Am J Surg Pathol 1991;15:233-45.

113. Kapadia SB, Frisman DM, Hitchcock CL, Ellis GL, Popek EJ. Melanotic neuroectodermal tumor of infancy. Clinicopathologic, immunohistochemical, and flow cytometric study. Am J Surg Pathol 1993;17:566-73.

\section{Book Review}

\section{MacSween RNM, Burt AD, Portman BC, Ishak KG, Scheuer PJ, Anthony PP (editors): Pa- thology of the Liver, 4th edition, 895 pp, Churchill Livingstone, London, 2001 (\$295.00).}

Since I have recently used on these pages the term "breviary" for the short liver biopsy book written by Peter Scheuer (one of editors of this text), I have no choice but to call the present book a psalmody-a collection of hepatologic psalms for all liturgical occasions. Or even more appropriately, maybe I should call it the ultimate sacred text penned by hepato- hierophants, a neologism of mine constructed to mean that the authors are high-ranked priests of hepatology or interpreters of divine truth encoded in medical literature on liver diseases and liver biopsy slides!

Befitting a text that focuses on the heaviest internal organ in the body, this is a heavy book. In part this is due to the fact that it was published on heavy-duty paper, and in part owing to the number of pages. From the previous edition it has gained more than 100 pages. It is divided into 18 chapters, discussing essentially all facets of liver pathology. All chapters have been updated from the previous edition. The aspects of liver anatomy and pathophysiology relevant to the understanding of morphologic changes are reviewed also. The recent contributions of modern cell and molecular biology are highlighted and placed in proper context. Like before, the clinical pathological correlations are the mainstay of the book. Morphologic manifestations of liver diseases are illustrated with highquality, well-chosen color photographs. The references are up-to-date and include many papers dating to years 1998-2000. Obviously the book was aimed at hospital-based diagnostic pathologists, but it will be consulted by clinical hepatologists as well.

Hepatopathology is a growing field, and to quote Hans Popper from his 1979 foreword to the first edition, this is just the "latest progress report and not a final dogma" of that discipline. Some old controversies, such as the concepts of hepatic acinus and lobule, are given new airing. There are a lot of new data on viral and immunologic diseases and liver transplants. The list of hepatic drug reactions is getting longer on a daily basis. It is a reflection of our times that the authors are not even trying to be absolutely up-todate (a Sisyphean task!) but list URLs for those readers who want to use computers to keep up on their own with the flood of information.

This is a beautiful book full of useful facts that will be appreciated by diagnostic pathologists. I used it during the past 2 months to look up specific entities encountered in our hospital practice, and I found it very user friendly and complete. On occasion I found that some topics need to be updated; for example, in the past 10 years we have learned much more about the sickle cell hepatopathy. The data on some tumors, such as embryonal sarcoma of the liver, need updating. Fine needle aspiration biopsy probably also needs a bit more space.

In the foreword written by V. Desmet, we are reminded that " Like the building of cathedrals the building-up of medical diagnoses requires not only the carving of stones, but also the vision and perspective of the builders." There is no doubt that this book is, like a cathedral, aweinspiring. To continue the quote, "Countless problems await ... future hepatologists armed with future microscopes" (to solve them all). Until then, this remains the best compilation of our current knowledge of hepatopathology.

Ivan Damjanov

University of Kansas School of Medicine

Kansas City, Kansas 